\title{
Investigating the Impact of Convergent vs. Divergent Assessment on ESL Students' Anxiety and Test Performance
}

\author{
Azar Saeedi Nasab (Corresponding author) \\ Department of Language and Linguistics \\ Islamic Azad University-UAE Branch,Dubai,UAE \\ E-mail: azar489@yahoo.com \\ Esmaeil Bagheridoust \\ Graduate Department of TESL and Translation Studies \\ Islamic Azad University-South Tehran Branc,Iran \\ Address: No. 156, Khaje Abdollah Ansary Ave., Seyed Khandan \\ Tel.: +982122861186 E-mail: esmaeilbagheridoust@gmail.com \\ Kourosh Karimi \\ Islamic Azad University-North Tehran Branch,Iran \\ E-mail: cyrusk1971@yahoo.com
}

Received: 22-12-2013

Accepted: 26-01-2014

Published: 01-05-2014

doi:10.7575/aiac.ijalel.v.3n.3p.65

URL: http://dx.doi.org/10.7575/aiac.ijalel.v.3n.3p.65

\begin{abstract}
Language assessment with its eye-catching nature, casts its spell on many researchers, spurring on them to study its telling role in different arenas. The present study with a closer look to the realm, keeps one eye on two fresh approaches in assessment, namely convergent and divergent, and the other one on anxiety in a bid to slash its negative impact on students' performance. The researchers resort to a correlational method with Ex Post Facto design, along with different tests, to forward the foregoing aim; discovering and appraising the degree of relationship stands between the two variables. Analyzing data gathered in this hybrid research on 55 young Iranian male and female students in two schools, located in United Arab Emirates (UAE), the researchers reaped findings which bore witness to the main proposed hypotheses, illustrating that divergent assessment (DA) was more effective in reducing learners' test anxiety level in comparison with convergent assessment (CA) which, in turn, led up to better performance in the participants. Some implications for EFL teachers, to include the similar strategies in their lesson plan, offered at the very end which is followed by proposing some new horizons for further studies and investigations.
\end{abstract}

Keywords: Divergent Assessment, Convergent Assessment, Dynamic Assessment, Test Anxiety, Test Performance

\section{Introduction}

For many years teaching draw gazes, turning the prime importance of assessment into the forgotten corner of minds. All the same, in recent years the construct, tied up with teaching and came to the fore, winning the ground of research in different realms. The concept of assessment, which of its nature, is an umbrella term covers instruments, administrators and quantitative methods, referring to the on-going collection of data on the language ability of learners or their achievements that, in turn, provides a fertile ground for them to be active participants and well on the way in learning process; for the finishing touch, leading teachers to be accountable for the learning opportunities they provide for students. Assessment, with a closer look, is different from evaluation in that the second term underscores the overall performance of students in a program and has nothing to do with what individuals do; moreover, assessment should not be counted as testing which is its sub-component (Brindley, 2002).

\section{A Glance at Types of Assessment}

Assessment runs the gamut of techniques and approaches for appraising students' skills and abilities. What follows this line is actually a glance over some of the most important types of it. For a start, Informal Assessment is among the list of names being considered as assessment types. The non-standardized method of evaluating learners' progress done by the teacher, along with its name, brings its opposite camp dubbed as Formal Assessment which is referred to standardized, norm-referenced formal assessments including published tests generally advanced by experts. Digging more around the realm, one can spot the title of Summative Assessment, a final assessment of progress that administered at the end of the instructional course, vis-à-vis Formative Assessment, the ongoing assessment through which teachers monitors students continuously throughout the instructional period. Taking different perspective, assessment can also be classified in term of being Criterion-Referenced or Norm referenced that the constructs point to the process of comparing students' performance with a list of behavioral objectives or with regard to other students' outcomes, respectively. 
Among the names lies in the list, a group, under the banner of Performance-based assessment, stands and brings an alternative to standardized achievement tests, putting an attempt to produce authentic products or simulate real life activities in "authentic" real world settings. Portfolio assessment is another noting class that refers to gleaning pieces of information at different times about the learners' knowledge which gives them multiple chance to reflect on what they do and how they act, keeping the momentum in their moving forward. To wrap it up, each of the foregoing types along with other terms grabbed many eyes, with more of them putting bull in students' court such as self-assessment, peerassessment, dynamic assessment, etc. But what this paper is centered upon is convergent and divergent assessments that later on delineated in depth.

\section{What lies under CA and DA?}

The two assessment approaches of convergent and divergent is closely aligned with Vygotskian approach titled Zone of Proximal Development (ZPD) that refers to the development of a person's potential abilities (Leung, 2007) with the concept of mediation at its heart, outlining learning potential is the direct corollary to mediation and support provided by a more-advanced person or teacher. The advocates of assessments with such perspective, in another line of argument, claimed that the "structure" underlying abilities is holistic; i.e., there is "strong cohesion between the whole - that is, the structure itself - and its components" (Feuerstein, Rand, \& Rynders, 1988, p. 10), ruling our "stages of development" earlier proposed by Piaget in another reasoning line. Moreover, they offer some form of assistance to influence and unmask students' potential for change (Campione, 1989). Counting students as active modifiers, lovingly accepting low-functioning children as they are, having optimistic takes about children's potentialities and, providing breeding ground for them to off the limit are of some standpoints should be taken into account in this arena. The idea of present-to-future cognitive development lies at keystone to the approach which aims at fully understanding a person's potential to progress and unmasking his or her ZPD (Leung, 2007).

\section{Convergent assessment}

Convergent and divergent assessments were advanced first by Hudson in 1966, taking their names from two approaches a student requires in a bid to complete the assessment, namely convergent and divergent thinking. From this very perspective, methods of assessment vary according to whether the teacher counts the task as convergent or divergent (Torrance \& Pryor, 1998). Convergent assessment keeps eyes trained on the preposition "if" in question "if the learner knows, understands, or can do with a predetermined thing', stressing that the problematic situation in which the students are mired has only one correct answer obtained from the available information.

Based on what Torrance and Pryor (2001) postulated, CA characterized by a detailed planning, is generally fulfilled through the channel of closed questions and tasks. Given that, using tick-lists and can-do statements, assessments as such prefer pseudo-open questioning and focusing on the contrasting errors with correct responses. In a nutshell, the type can be described as behavioristic with this purpose to assess in a linear way and is of the student, executed by the teacher (Torrance \& Pryor, 1998).

\section{Divergent Assessment}

Like CA, divergent assessment loans its name from a thinking approach titled with the same term of divergent referring to the production and use of several thoughts and strategies to reason a certain problem out and is assumed to be a good predictor of creative enactment as well as performance (Ranco, as cited in Sak \& Maker, 2005). Mainly, divergent thinking places attention on both quantity and quality of takes and thoughts being generated by the problem-solver or student in response to language prompts (Guilford, as cited in Sak \& Maker, 2005). Given that, it put stress on the learner's understanding rather than the agenda of the assessor. The crux of the matter in this line is the process, in effect, aims at unveiling what the learner knows, understands and can do.

Divergent assessment can be "characterized by less detailed planning where open questioning and tasks are of more relevance" (Torrance and Pryor, p. 617). Flexible planning, open forms of recording, emphasizing the learners' understanding, open tasks, open questioning and descriptive, qualitative feedback are of other features assessments of this type are blessed with. In point of fact, strives toward teaching in the zone of proximal development alludes to the social constructivist view of education such approach takes (Torrance \& Pryor, 1998).

Needless to say, due the nascent stages divergent assessment stands on, researchers have far to go so as to know more about its various forms and continued improvement is still needed on some dimensions including more empirical research from real classrooms which its amount is literally well below the satisfying level. With this in mind, the researcher aims to take the cognizance of such area and study its effect on reducing students' anxiety which takes a toll on performance and is defined, in language classrooms, as an apprehension over frequent testing, that may become a source of defeat for learners, as their proficiency is evaluated while it is being acquired (Toth, 2010).

\section{Method}

\subsection{Participants}

Participants of the study were 55 Iranian students, 36 male and 19 female, aged between 13 and 15, who studied in two Iranian schools located in two different cities of UAE named in this research as Site A and Site D. The background variables of the participants including ethnicity, nationality, parent education, and students ELL statuses were not taken into account directly because it would add more complexity. 


\subsection{Design}

The present hybrid research with a correlational method of Ex Post Facto design, and through the ordinal scale sought to discover, measure, and determine the degree of relationship among the four variables of anxiety, test performance, convergent and divergent assessment, as well as any bearing they might have on each other.

\subsection{Procedure}

To fulfill the aims determined in this probe, for the start, a piloted and translated form of CTAS along with PET were administered among participants so as to let the researcher observe their levels of anxiety and proficiently, respectively; illustrating the standing rough homogeneity among the students as a result, prior to running any other phase.

Thereupon the level, convergent assessment through an oral exam and based on a free discussion with its topics derived from the course materials, was implemented. To do so, participants came on the same day in groups of five to answer the questions and interact with each other under the researcher's and their own teacher's supervision, using the instructors' ideas for evaluating their performance including pronunciation, vocabulary, grammar and fluency. The same assessment of CA was run, this time for appraising their reading ability through a standardized close-test which covered all the course material and in a format similar to the TOFEL reading comprehension examinations. Thereafter, CTAS for the second time challenged students' anxiety level, and this time to crystalize the level which had been influenced by CA assessing process.

Passing through the foregoing stages, the study entered this phase in which the divergent assessment came to the board. Given that, the same aforesaid abilities of the students evaluated, via DA considering. As for speaking, the students were asked to prepare themselves for a group presentation, in front of the class, on a topic selected from their course material and according to the instructions provided. Regarding reading ability, participants were asked to read their worksheet and then answer the questions. Last of all, for the third time the test of anxiety and for the second time PET were run in a bid to find out whether students showed lower anxiety. It is worthwhile noting that the reliability of all tests used in this study was analyzed and approved through Cronbach's Alpha.

\subsection{Instruments}

Among the apparatus utilized in forwarding the study, a type of standard anxiety test named Children's Test Anxiety Scale (CTAS), was used in the first instance comprising a series of closed questions including 30 Likert type items. It is noteworthy, the test in the piloting phase went through necessary changes and its rendition was decided to be given to students on account of their problems in translating the questions.

A series of Topics germane to the lessons covered during the course selected by the teacher and students to evaluate the participants in their speaking abilities. In addition, the Preliminary English Test (PET) was another test used in this study so as to evaluated students general proficiency prior to runny any other test. The inquirers piloted the PET test and the reliability obtained was 0.81 .

Moreover, a standardized close-test which covered all the course material and in a format similar to TOFEL reading comprehension examinations administered among students so as to evaluate their reading ability. The researchers piloted the TOEFL test and they obtained the reliability index of 0.93 .

\section{Data Analysis}

\subsection{Normality Assumption}

To open up the report, the two assumptions of normality and homogeneity were met and approved in the analysis part. Regarding normality assumption, which its related table was brought in the Appendix A, the ratio of skewness over its respective standard errors were within the ranges of $+/-1.96$, proving the data enjoyed a normal distribution.

\subsection{Reliability indices}

For meeting the reliability, all test results in this study through Cronbach's Alpha were calculated and analyzed. Given that, the outcomes reaped out of such process indicated high standing reliability both in Anxiety test (0.91) and PET (0.92). As for the speaking ability test, the analyzed outcome gained through Convergent and Divergent Assessment illustrated the reliability of 0.82 for both approaches. The result of reading tests was less reliable, but still acceptable, in the two assessments of Convergent (0.67) and Divergent (0.72), compared to a similar outcome in Speaking part which indicates 0.89 percent both DA and CA. We computed the inter-rater reliability using Pearson-product moment and we obtained the index of 0.87 . The foregoing numbers are highlighted in the related tables provided in Appendix C.

\subsection{Impact analysis}

Appraising the impact of the research process on students' performance in the interested realms, Paired Sample $t$-test was used. According to its result, depicted in Table 1, a significant difference (-11.17) was observed among students' performance in PET test 1 and PET test 2. But as for speaking, the outcome did not greatly change and the $t$ value of 0.368 showed no significant difference between the learners' test performance on speaking assessed through CA vs. DA. The eye-catching point belonged to the students' performance changed by means of divergent assessment of reading, and the $t$ value of -2.934 is the indicative of such a significant difference between the two kinds of assessment techniques. This index supports the hypothesis that divergent assessment does have a positive impact on the students' test performance by lowering the test anxiety level. For the details of the statistics, you can refer to Appendix C. 


\begin{tabular}{|c|c|c|c|c|c|c|c|c|c|}
\hline & & \multicolumn{5}{|c|}{ Paired Differences } & \multirow[b]{3}{*}{$\mathrm{T}$} & \multirow[b]{3}{*}{$\mathrm{df}$} & \multirow{3}{*}{$\begin{array}{l}\text { Sig. (2- } \\
\text { tailed) }\end{array}$} \\
\hline & & \multirow[b]{2}{*}{ Mean } & \multirow[b]{2}{*}{ Std. Deviation } & \multirow[b]{2}{*}{ Std. Error Mean } & \multicolumn{2}{|c|}{$\begin{array}{l}95 \% \text { Confidence Interval of } \\
\text { the Difference }\end{array}$} & & & \\
\hline & & & & & Lower & Upper & & & \\
\hline Pair 1 & PET1 - PET2 & -2.26852 & 1.49121 & .20293 & -2.67554 & -1.86150 & -11.179 & 53 & .000 \\
\hline Pair 2 & $\begin{array}{l}\text { CASPEAKING - } \\
\text { DASPEAKING }\end{array}$ & -.12963 & 2.59205 & .35273 & -.83712 & .57786 & -.368 & 53 & .715 \\
\hline Pair 3 & $\begin{array}{l}\text { CAREADING - } \\
\text { DAREADING }\end{array}$ & -1.87963 & 4.70742 & .64060 & -3.16451 & -.59475 & -2.934 & 53 & .005 \\
\hline
\end{tabular}

\subsection{Correlation analysis}

For analyzing the standing relationship among variables, Pearson Product correlation tests were utilized. The achieved result, Table 2, illustrated a high correlation between PET tests running at the outset and the end of the study with the index of 0.867 that double-approves of the validity and reliability of the tests. The same story was true about the two types of speaking assessments which depicted a high reliability (0.821) lied between CA and DA. As for reading, the index (0.374) with a low correlation between the two approaches of assessment indicated they were to some extent different in nature and process.

Investigation of correlation among the different variables in this study was the final phase of analysis. Based on that, the relationship between Anxiety test 1 and 2, was almost high (0.622), corroborating convergent assessment was not able to reduce the level of anxiety. Quite contrary, the low correlation (0.48) between anxiety 1 and anxiety 3 showed that the divergent assessment was quite effective in lowering the student's test anxiety level.

The other high correlation index was between CA speaking and DA speaking assessments $(0.821)$, whereas there stood a low correlation between their counterparts in assessing reading. The index of 0.374 in the depicted table was the indicative of such a fact. Another noting point refers to this line that no direct correlation was witnessed between test anxiety and PET tests as well as convergent and divergent assessment. But surprisingly, divergent assessment was quite effective in slashing the level of test anxiety and test performance.

Table 2. Correlations among Variables

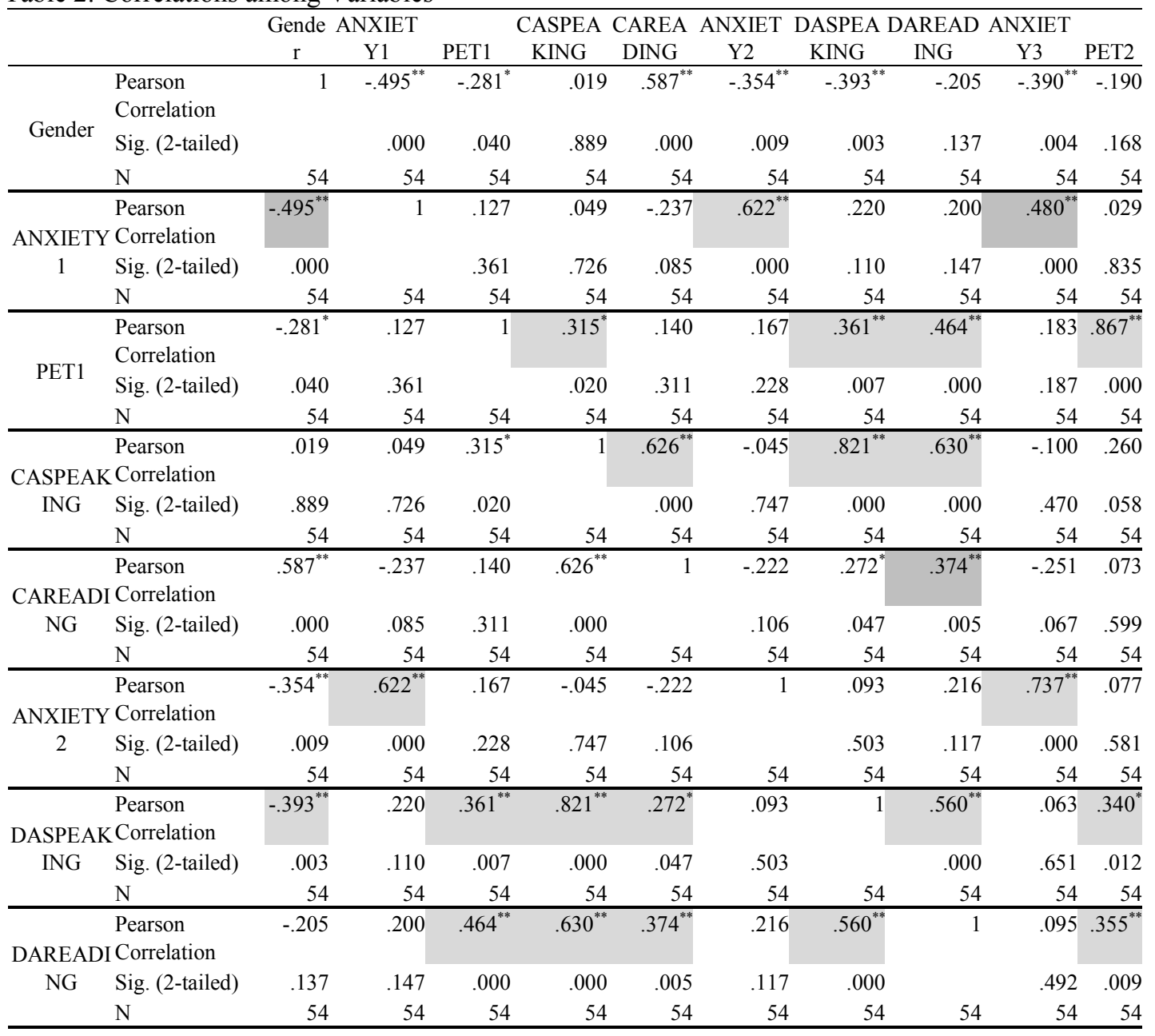




\begin{tabular}{rlrrrrrrrrrr}
\hline \multicolumn{2}{c}{$\begin{array}{l}\text { Pearson } \\
\text { ANXIETY Correlation }\end{array}$} & $-.390^{* *}$ & $.480^{* *}$ & .183 & -.100 & -.251 & $.737^{* *}$ & .063 & .095 & 1 & .109 \\
3 & Sig. (2-tailed) & .004 & .000 & .187 & .470 & .067 & .000 & .651 & .492 & & .433 \\
& $\mathrm{~N}$ & 54 & 54 & 54 & 54 & 54 & 54 & 54 & 54 & 54 & 54 \\
\hline \multirow{6}{*}{ PET2 } & Pearson & -.190 & .029 & $.867^{* *}$ & .260 & .073 & .077 & $.340^{* *}$ & $.355^{* *}$ & .109 & 1 \\
& Correlation & & & & & & & & & & \\
& Sig. (2-tailed) & .168 & .835 & .000 & .058 & .599 & .581 & .012 & .009 & .433 & \\
& $\mathrm{~N}$ & 54 & 54 & 54 & 54 & 54 & 54 & 54 & 54 & 54 & 54 \\
\hline
\end{tabular}

**. Correlation is significant at the 0.01 level (2-tailed).

*. Correlation is significant at the 0.05 level (2-tailed).

\section{Result and Conclusion}

As a result of the assessment of students in two different classes using divergent and convergent techniques, the researchers primarily figured out that there was no direct correlation between test anxiety and test performance. The same case was true with the correlation between the test anxiety and convergent/divergent assessment. However, the obtained results of anxiety tests, divergent and convergent assessments, and parallel PET tests indicated significant changes.

Regarding the foregoing outcomes, it can be concluded that divergent assessment was more effective in lowering a student's level of test anxiety and this helped students have a better test performance with a lower level of anxiety. It is worth noting that the strategies used in this research not only was effective for students but also impressed the teachers with its effects in improving assessment programs which, in turn, let them detect their own inner powers. The variables this paper centered around can be approached in other geographical areas, on other levels of students' proficiency and their effects can also be evaluated on languages skills and sub-skills other than the ones spotlighted in the present investigation.

\section{References}

Brindley, G. (2002). Issues in language assessment. In R.B. Kaplan (Ed.), The Oxford handbook of applied linguistics, Oxford University Press, pp. 459-470.

Campione, J.C. (1989). Assisted Assessment: Taxonomy of Approaches. Cambridge, England: Cambridge University Press, p.224.

Constant L. (2007). Dynamic Assessment: Assessment for and as Teaching? Department of Education and Professional Studies, King's College, University of London, SE1 9NH, United Kingdom.

Feuersten, R., Rand, Y. \& Rynders, J.E. (1988). Don't accept me as I am - Helping "retarded" people to excel. New York, Plenum Press.

Hudson, L. (1996). Contrary Imaginations: a psychological study of the English schoolboy”, Great Britain, Penguin books Ltd .

Sak, U. \& Maker, C. J. (2005). Divergence and convergence of mental forces of children in open and closed mathematical problems. International Education Journal, 6, 252-260.

Torrance, H., \& Pryor, J. (1998). Investigating Formative Assessment: teaching, learning and assessment in the classroom, Philadelphia, PA Open University Press.

Torrance, H., \& Pryor, J. (2001). Developing formative assessment in the classroom: Using action research to explore and modify theory. British Educational Research Journal, 27(5)615-631.

Toth, Z. (2010). A foreign language anxiety scale for Hungarian learners of English, Cambridge Scholars Publishing.

Appendix A

Descriptive Statistics ; Normality assumption

\begin{tabular}{|c|c|c|c|c|c|c|c|}
\hline & $\mathrm{N}$ & Minimum & Maximum & Mean & Std. Deviation & \multicolumn{2}{|c|}{ Skewness } \\
\hline & Statistic & Statistic & Statistic & Statistic & Statistic & Statistic & Std. Error \\
\hline Gender & 54 & 1.00 & 2.00 & 1.3519 & .48203 & .638 & .325 \\
\hline ANXIETY1 & 54 & 42.00 & 111.00 & 78.7222 & 16.33773 & .561 & .325 \\
\hline PET1 & 54 & 3.00 & 17.50 & 9.0185 & 2.90732 & .420 & .325 \\
\hline ANXIETY2 & 54 & 36.00 & 106.00 & 66.5556 & 15.63579 & 1.039 & .325 \\
\hline CASPEAKING & 54 & 6.00 & 19.00 & 13.4815 & 3.73530 & -.339 & .325 \\
\hline CAREADING & 54 & 4.00 & 20.00 & 12.3981 & 4.16565 & .060 & .325 \\
\hline DASPEAKING & 54 & .00 & 19.00 & 13.6111 & 4.54087 & -1.308 & .325 \\
\hline DAREADING & 54 & 2.00 & 20.00 & 14.2778 & 4.24894 & -.806 & .325 \\
\hline ANXIETY3 & 54 & 30.00 & 108.00 & 45.8519 & 16.66474 & 1.151 & .325 \\
\hline PET2 & 54 & 6.00 & 18.00 & 11.2870 & 2.87081 & .340 & .325 \\
\hline Valid N (listwise) & 54 & & & & & & \\
\hline
\end{tabular}


Appendix B-1

Reliability Statistics of Anxiety Questionnaire

\begin{tabular}{|c|c|c|}
\hline \multicolumn{3}{|c|}{ Reliability Statistics of Anxiety Questionnaire } \\
\hline \multirow{4}{*}{ Cronbach's Alpha } & Cronbach's Alpha & $\mathrm{N}$ of Items \\
\hline & Based on & \\
\hline & Standardized & \\
\hline & Items & \\
\hline .911 & .911 & 30 \\
\hline
\end{tabular}

\section{Appendix B-2}

\begin{tabular}{rcr}
\hline \multicolumn{3}{c}{ Reliability Statistics (PET) } \\
\hline Cronbach's Alpha & $\begin{array}{c}\text { Cronbach's Alpha } \\
\text { Based on } \\
\text { Standardized Items }\end{array}$ & N of Items \\
\hline \multicolumn{3}{c}{.929} \\
\hline
\end{tabular}

\section{Appendix B-3}

Reliability Statistics (CA Speaking)

$$
\text { Cronbach's Alpha }
$$

$$
\text { Based on }
$$

Cronbach's Alpha Standardized Items N of Items

\begin{tabular}{rrr}
.892 & Standardized Items & N of Items \\
\hline
\end{tabular}

Reliability Statistics (DA Speaking)

Cronbach's Alpha

Based on

Cronbach's Alpha Standardized Items N of Items

Reliability Statistics (DA Reading)

Reliability Statistics (CA Reading)

\begin{tabular}{rrr}
\hline Cronbach's Alpha & $\begin{array}{c}\text { Cronbach's Alpha } \\
\text { Based on } \\
\text { Standardized Items }\end{array}$ & N of Items \\
\hline .673 & .762 & 20 \\
\hline
\end{tabular}

\begin{tabular}{rrr}
\hline Cronbach's Alpha & $\begin{array}{c}\text { Cronbach's Alpha } \\
\text { Based on } \\
\text { Standardized Items }\end{array}$ & N of Items \\
\hline .721 & .802 & 20 \\
\hline
\end{tabular}

\section{Appendix B-5}

\begin{tabular}{|c|c|c|c|c|c|}
\hline & & Mean & $\mathrm{N}$ & Std. Deviation & Std. Error Mean \\
\hline \multirow[t]{2}{*}{$\overline{\text { Pair } 1}$} & PET1 & 9.0185 & 54 & 2.90732 & .39564 \\
\hline & PET2 & 11.2870 & 54 & 2.87081 & 39067 \\
\hline \multirow[t]{2}{*}{ Pair 2} & CASPEAKING & 13.4815 & 54 & 3.73530 & .50831 \\
\hline & DASPEAKING & 13.6111 & 54 & 4.54087 & .61793 \\
\hline \multirow[t]{2}{*}{ Pair 3} & CAREADING & 12.3981 & 54 & 4.16565 & .56687 \\
\hline & DAREADING & 14.2778 & 54 & 4.24894 & .57821 \\
\hline
\end{tabular}

Paired Samples Statistics 


\section{CHILDREN`S TEST ANXIETY SCALE (CTAS)

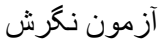

كام و نام خانو ادخى:

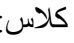

عبار ات زير را با دقت خو انده و دور كزينه اى كه به بهترين وجه حائ حالات و احساس شما را موقع امتحان توصيف ميكند بكى دايره بكشيد.

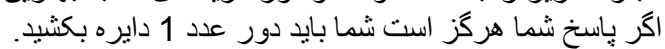

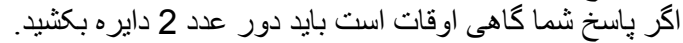

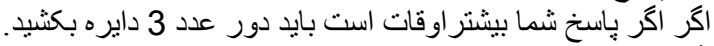
اكر ياسخ شما هميشه است بايد دور عدد 4 دايره بكثيد.

هركز

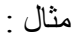

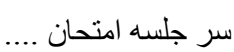

\section{2}

1

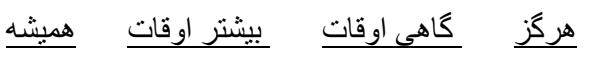

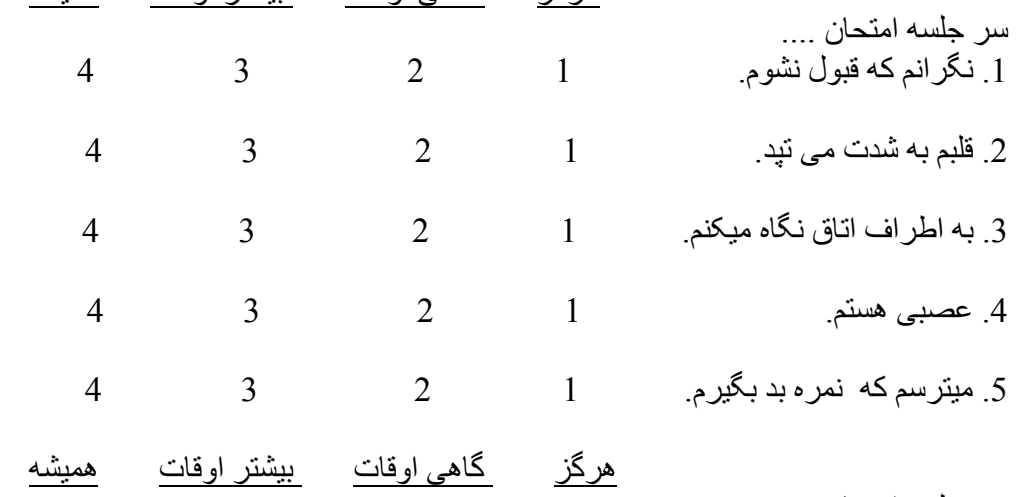

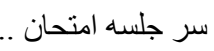

6. 7.
4
4

هركز كاهى اوقات بيثتر اوقات

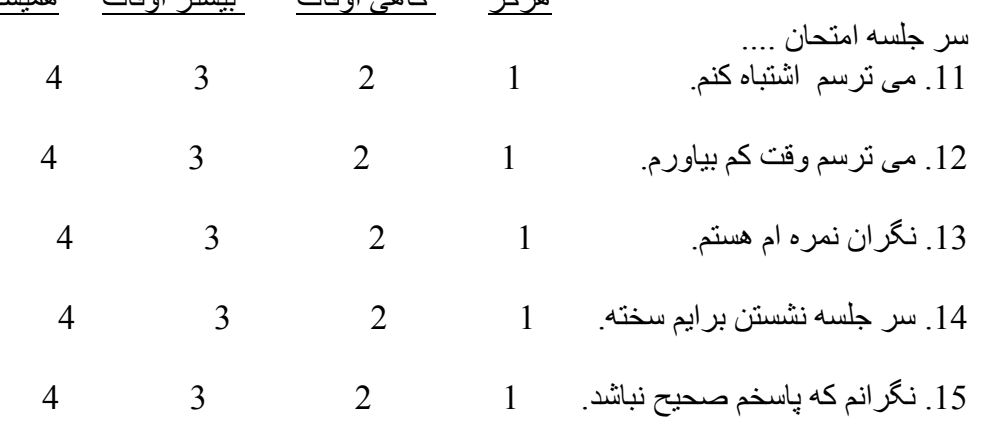

هركز كاهى اوقات بيثنر اوقات هيثن

16
4




\begin{tabular}{|c|c|c|c|c|}
\hline 4 & 3 & 2 & 1 & 18. به ديكران نحاه ميكنم. \\
\hline 4 & 3 & 2 & 1. & 19. فكر ميكنم بيشتر جوابهايم غلط است \\
\hline 4 & 3 & 2 & 1 & 20. احساس كرما ميكنم. \\
\hline هميشه & بيشتر اوقات & كاهى اوقات & هركز & \\
\hline 4 & 3 & 2 & 1 & 21. نكر ان سختى امتحانم. \\
\hline 4 & 3 & 2 & ז. 1 r 1 & 22. سعى ميكنم امتحان را سريع تمام كنم \\
\hline 4 & 3 & 2 & 1 & 23. ستانم ميلرزند . \\
\hline 4 & 3 & 2 & 1 & 24. فكر ميكنم اكر رد شوم جه ميشود. \\
\hline 4 & 3 & 2 & 1 & 25. وسط امتحان بايد دستثويى بروم. \\
\hline هميشـه & بيشتر اوقات & كاهى اوقات & هركز & سير حلسيه امتحا. \\
\hline 4 & 3 & 2 & 1 & 26. باهايم را هى تكان ميدهم. \\
\hline 4 & 3 & 2 & 1 & 27. فكر ميكنم امتحانمو بد دادم. \\
\hline 4 & 3 & 2 & 1 & 28 احساس ترس دارم. \\
\hline 4 & 3 & 2 & 1 & 29. نكر ان سرزنش و الدينم هستم. \\
\hline 4 & 3 & 2 & 1 & 30. به يك جا خيره ميشوم. \\
\hline
\end{tabular}

